\title{
COMPARATIVE ANALYSIS OF ANTHROPOMETRIC INDEXES TO PREDICT HYPERTENSION RISK IN EMPLOYEES CIMAHI CITY
}

\author{
Debri Rizki Faisal, ${ }^{1}$ Syahrizal Syarif ${ }^{2}$ \\ ${ }^{1}$ Field Epidemiology Training Program, Indonesia University \\ ${ }^{2}$ Faculty of Public Health, Indonesia University
}

\begin{abstract}
Background: Anthropometric indicator such as Body Mass Index (BMI), Waist Circumference (WC) and Waist to Height Ratio (WHtR) can be used to predict the risk of hypertension. This study aims to compare anthropometry in predicting the risk of hypertension in employees in Cimahi City.

Methods: The design study was cross-sectional with diagnostic test. This study used secondary data of NonCommunicable Diseases (NCD) screening 827 employees with age $\geq 15$ years. The ROC (receiver operating characteristic) curves were analyzed to identify the optimal cut-off points and to compare the capacity of anthropometric indexes for prediction hypertension by gender using Stata.13 software.

Result: The hypertension cases in men $65.32 \%$ was higher than women $34.68 \%$. The Area under the Curve $(A U C)$ of WC $0.70 \quad(95 \% C I=0.66-0.74)$ was more than WHtR $0.66 \quad(95 \% C I=0.62-0.70)$ and BMI 0.64 (95\%CI=0.60-0.69). Based on gender, the highest AUC of men was WC $0.69(95 \% C I=0.64-0.75)$ and the highest AUC of women was WC and WHtR 0.67 (95\%CI=0.60-0.74). The optimal cut-off points in predicting hypertension were BMI 25.89 ( $\mathrm{Sn}=67.05 \%, \mathrm{Sp}=57.95 \%), \mathrm{WC} 90 \mathrm{~cm}(\mathrm{Sn}=76.30 \%, \mathrm{Sp}=54.74 \%)$ and $\mathrm{WHtR} 0,56$ $(\mathrm{Sn}=68.79 \%, \mathrm{Sp}=59.02 \%)$.
\end{abstract}

Conclusion: Based on the result, waist circumference can be used as an anthropometric index indicator better than WHtR and BMI in predicting hypertension risk in employees Cimahi City.

Keywords: Hypertension, obesity, diagnostic test

\section{ANALISIS KOMPARATIF INDEKS ANTROPOMETRI UNTUK MEMPREDIKSI RISIKO HIPERTENSI PADA PEGAWAI DI KOTA CIMAHI}

\begin{abstract}
ABSTRAK
Latar Belakang: Indeks antropometri seperti Indeks Massa Tubuh (IMT), Lingkar Pinggang (LP) dan Rasio Lingkar Pinggang Tinggi Badan (RLPTB) dapat memprediksi risiko hipertensi pada seseorang. Penelitian ini bertujuan membandingkan indeks antropometri untuk memprediksi risiko hipertensi pada pegawai di Kota Cimahi.

Metode: Desain studi Cross Sectional dengan pendekatan Uji Diagnostik. Penelitian ini menggunakan data sekunder hasil skrining Penyakit Tidak Menular (PTM) pada pegawai yang berumur $\geq 15$ tahun yaitu 827 orang. Analisis Receiver Operating Characteristic (ROC) untuk mendapatkan cut-off point yang optimal dan membandingkan kemampuan indeks antropometri dalam memprediksi risiko hipertensi berdasarkan jenis kelamin dengan menggunakan software Stata.13.

Hasil Penelitian: Hipertensi lebih banyak laki-laki 65.32\% dibandingkan perempuan 34.68\%. Analisis kurva ROC didapatkan nilai AUC LP $0.70(95 \% \mathrm{CI}=0.66-0.74)$ lebih tinggi dibandingkan dengan RLPTB 0.66 $(95 \% \mathrm{CI}=0.62-0.70)$ dan IMT $0.64(95 \% \mathrm{CI}=0.60-0.69)$. Berdasarkan jenis kelamin, nilai AUC paling tinggi pada laki-laki yaitu LP 0.69 (95\%CI=0.64-0.75) sedangkan pada perempuan nilai AUC paling tinggi pada LP dan RLPTB yaitu 0.67 (95\%CI=0.60-0.74). Cut off point yang optimal pada masing-masing indeks antropometri dalam memprediksi hipertensi yaitu IMT 25.89 ( $\mathrm{Sn}=67.05 \%$, Sp=57.95\%, LP $90 \mathrm{~cm}$ ( $\mathrm{Sn}=76.30 \%, \mathrm{Sp}=54.74 \%$ dan RLPTB $0.56(\mathrm{Sn}=68.79 \%, \mathrm{Sp}=59.02 \%)$.
\end{abstract}

${ }^{1}$ Correspondence Address: Debri Rizki Faisal, Field Epidemiology Training Program, Universitas Indonesia, Depok, Indonesia email : debririzkif.fetpui@gmail.com 
Kesimpulan: Berdasarkan dari hasil penelitian, lingkar pinggang dapat digunakan sebagai indikator indeks antropometri yang lebih unggul dari pada RLPTB dan IMT dalam memprediksi risiko hipertensi pada pegawai di Kota Cimahi.

Kata Kunci: Hipertensi, obesitas, uji diagnostik

\section{INTRODUCTION}

Hypertension is one of the death causes in the world with an estimated 9.4 million die every year with complication heart disease $45 \%$ and stroke $51 \%{ }^{1}$ The prevalence of hypertension in Indonesia was $25.8 \%$ (2013) and through increased become $34.1 \%$ (2018). ${ }^{2.3}$ The trend of obesity based on Body Mass Index (BMI) was also increase10.5\% (2007), 14.8\% (2013) and $21.8 \%$ (2018). Central obesity based on waist circumference measurements in 2007 $(18.8 \%)$ increased in 2018 (31.0\%). ${ }^{2}$ Hypertension is strongly associated with the increase of overweight or obesity ${ }^{4.56 .7 .8 .9}$ and usually used as a standard indicator to predict the risk of hypertension. ${ }^{10.11}$

Body Mass Index, Waist circumference, and Waist to Height Ratio (WHtR) are an anthropometric index which usually used to measure adiposity of fat in the body. ${ }^{12}$ The anthropometric index can also be used to predict the risk of hypertension for someone with a certain cut-off point. ${ }^{13}$

Generally, World Health Organization (WHO) recommended that BMI cut-off points are classified on three levels, normal (18.5-24.9 $\left.\mathrm{kg} / \mathrm{m}^{2}\right)$, overweight $\left(25.0-29.9 \mathrm{~kg} / \mathrm{m}^{2}\right)$ and obesity $\left(\geq 30.0 \mathrm{~kg} / \mathrm{m}^{2}\right)$. However, in 2004 , the expert's consultation of WHO redefined BMI cut-off points is only overweight $\left(23 \mathrm{~kg} / \mathrm{m}^{2}\right)$ and obesity $\left(27.5 \mathrm{~kg} / \mathrm{m}^{2}\right.$ ) for Asian populations. ${ }^{13}$ The studies from several countries in Asia also found different cut-off points, such as China $\left(23.5 \mathrm{~kg} / \mathrm{m}^{2}\right)$, Vietnam $\left(20.5 \mathrm{~kg} / \mathrm{m}^{2}\right)$, Egypt $(27$ $\mathrm{kg} / \mathrm{m}^{2}$ ) and Korea $\left(22.7-23.3 \mathrm{~kg} / \mathrm{m}^{2}\right) .{ }^{14.15 .16}$ The Ministry of Health Indonesia apply a cut-off point $\left(\geq 27 \mathrm{~kg} / \mathrm{m}^{2}\right)$ lower than the WHO standard for the indicator of obesity. ${ }^{17}$
Waist circumference (WC) is alternative clinical method that relevant use to assess adiposity. BMI provides a marker of overall adiposity whereas WC provides a surrogate marker of abdominal adiposity and is the best association to visceral fat mass. Higher levels of WC are strongly associated with risk factors for and incidence of cardiometabolic disease. ${ }^{18}$ Cutoff points for a waist circumference of Southeast Asians, Japan, and China are $90 \mathrm{~cm}$ for men and $80 \mathrm{~cm}$ for women, lower than Europeans $($ men $=94 \mathrm{~cm}$ and women $=80$ $\mathrm{cm}) .{ }^{15}$ Indonesia has been using standard cut-off point for waist circumference $90 \mathrm{~cm}$ for men and $80 \mathrm{~cm}$ for women. ${ }^{3}$

Although BMI and WC are widely used in clinical practice and have been applied in several studies, there are still some limitations with these indicators. The use of the BMI does not reflect differences in body composition according to gender, age, and ethnicity. The main limitation of the WC is that the use of this measure in isolation may underestimate or overestimate the health risks for tall and short individuals with similar WCs. Several authors have proposed the use of waist to height ratio (WHtR) as a better indicator of abdominal obesity. This measure corrects the WC according to the individual's height and offers a strong correlation with cardiometabolic disease. ${ }^{19}$

Several studies published the important to reclassify the anthropometric index cut-off point in Asian population require BMI and WC lower than the general population in the world. ${ }^{15}$ Determining the obesity cut-off point is essential to prevent and reduce the risk of 
cardiovascular disease which complication due to hypertension. Based on the problems, this study aims to compare the anthropometric index between BMI, WC, and WHtR in predicting the risk of hypertension in employees in Cimahi City.

\section{METHODS}

The design study was cross-sectional with the diagnostic test approach. The cross-sectional study is a measurement between exposure and outcome at one time simultaneously. Diagnostic tests in this study are used to validity screening the population with anthropometric index approach to predict the risk of hypertension. The diagnostic test has the purpose of assessing the validity and reliability of a test in detecting the possibility of an illness earlier (early detection). Validity includes sensitivity and specificity. The sensitivity and specificity indicated the best cut-off points for the hypertension risk. Sensitivity was defined as the ratio of correctly identified hypertensive individuals, and specificity was defined as the ratio of correctly identified normotensive individuals.

Hypertension is a clinical condition characterized by Systolic blood pressure more or equal to $140 \mathrm{mmHg}$ and or Diastolic blood pressure more or equal to $90 \mathrm{mmHg} .{ }^{11.20}$ The anthropometric index approach used the Body Mass Index (BMI), Waist Circumference (WC) and Waist to Height Ratio (WHtR). BMI is the result of the calculation between bodyweight (kg) divided by height $\left(\mathrm{m}^{2}\right)$. WC is measurements from the midpoint between the lowest rib point and the arch endpoint of the groin/ pelvis then horizontally circling the waist and abdomen back towards the midpoint at the beginning of measurement. ${ }^{21} \mathrm{WHtR}$ is a calculation of waist circumference divided by height.
This study used secondary data of Posbindu PTM (screening of NonCommunicable Disease) for employees in the Cimahi City in March 2018. The samples are employees who participated in screening examination with data eligible to be analyzed with a total of samples 827 people.

Data were analyzed using software Stata13 (Stata Corporation, College Station, TX, the USA with serial number: 501306208483). Data were analyzed by univariate and bivariate analysis. Diagnostic tests using the Receiver Operating Characteristic (ROC) curve analysis to identify the best cut-off points of specificity and sensitivity, then evaluate and compare the predictive capacity of the anthropometric indicators for the hypertension outcome by age group in men and women $(<40$ years and $\geq 40$ years).

The areas under ROC curves provided the overall probability of the anthropometric indicator correctly classifying the presence or absence of illness. A larger area under the ROC curve indicated a higher predictive power of the indicator. The AUC value is between $0.5-1$; the test is useful if AUC $\geq 0.7$. The selected cutoff points had the greatest concomitant sensitivity and specificity. The significance level adopted for all analyses was 5\% with a confidence interval of $95 \%$.

\section{RESULTS}

Table.1 showed that hypertension was higher in male 113 people $(65.32 \%)$ than female 60 people (34.68\%). The mean age of hypertension employees was $46.86 \pm 9.02$ years, higher than employees with normotensive 39.53 \pm 10.22 years. BMI in employees with hypertension mean $27.75 \pm 5.41$ higher than the BMI of employees with normotensive $25.40 \pm$ 4.42 . 
Table.1

Characteristics Subject of Study

\begin{tabular}{|c|c|c|c|c|c|c|}
\hline \multirow{2}{*}{ Variable } & \multicolumn{2}{|c|}{ Over all $(n=827)$} & \multicolumn{2}{|c|}{ Hypertensive $(n=173)$} & \multicolumn{2}{|c|}{ Normotensive $(n=654)$} \\
\hline & $\mathbf{n}$ & $\%$ & $\mathbf{n}$ & $\%$ & $\mathbf{n}$ & $\%$ \\
\hline \multicolumn{7}{|l|}{ Gender } \\
\hline Men & 414 & 50.06 & 113 & 65.32 & 301 & 46.02 \\
\hline Women & 413 & 49.94 & 60 & 34.68 & 353 & 53.98 \\
\hline Age & \multicolumn{2}{|c|}{$41.07 \pm 10.41$} & \multicolumn{2}{|c|}{$46.86 \pm 9.02$} & \multicolumn{2}{|c|}{$39.53 \pm 10.22$} \\
\hline BMI & \multicolumn{2}{|c|}{$25.90 \pm 4.74$} & \multicolumn{2}{|c|}{$27.75 \pm 5.41$} & \multicolumn{2}{|c|}{$25.40 \pm 4.42$} \\
\hline \multicolumn{7}{|l|}{ WC } \\
\hline Men & \multicolumn{2}{|c|}{$92.99 \pm 10.50$} & \multicolumn{2}{|c|}{$98.03 \pm 9.59$} & \multicolumn{2}{|c|}{$91.10 \pm 10.21$} \\
\hline Women & \multicolumn{2}{|c|}{$86.92 \pm 10.50$} & \multicolumn{2}{|c|}{$92.75 \pm 10.43$} & \multicolumn{2}{|c|}{$85.93 \pm 10.21$} \\
\hline WHtR & \multicolumn{2}{|c|}{$0.56 \pm 0.068$} & \multicolumn{2}{|c|}{$0.59 \pm 0.068$} & \multicolumn{2}{|c|}{$0.55 \pm 0.065$} \\
\hline
\end{tabular}

The mean waist circumference in male hypertension was $98.03 \pm 9.59 \mathrm{~cm}$ higher than the waist circumference of male normotensive $91.10 \pm 10.21 \mathrm{~cm}$. The mean waist circumference in female hypertension higher than female normotensive. The waist to height ratio in employees with hypertension was higher than normotensive.

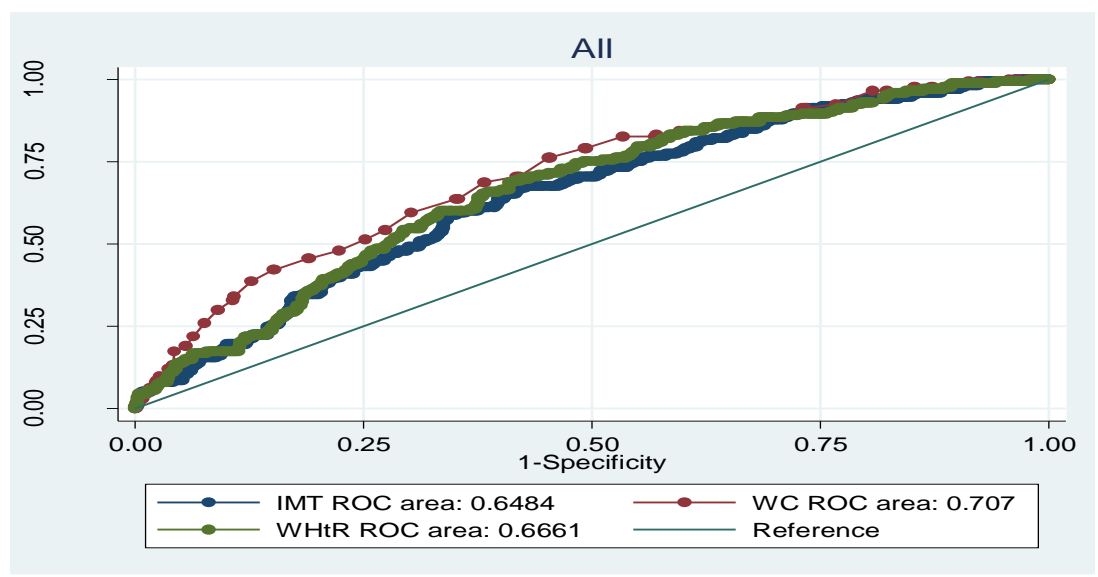

\section{Receiver Operating Characteristic (ROC) Curve between BMI, WC, and WHtR in Prediction of Hypertension}

Based on graph.1 results of ROC curve analysis showed that the area under the curve (AUC) of WC was $0.70(95 \% \mathrm{CI}=0.66-0.74)$ higher than $\mathrm{WHtR} 0.66(95 \% \mathrm{CI}=0.62-0.70)$ and $\mathrm{BMI} 0.64(95 \%$ $\mathrm{CI}=0.60-0.69)$. 

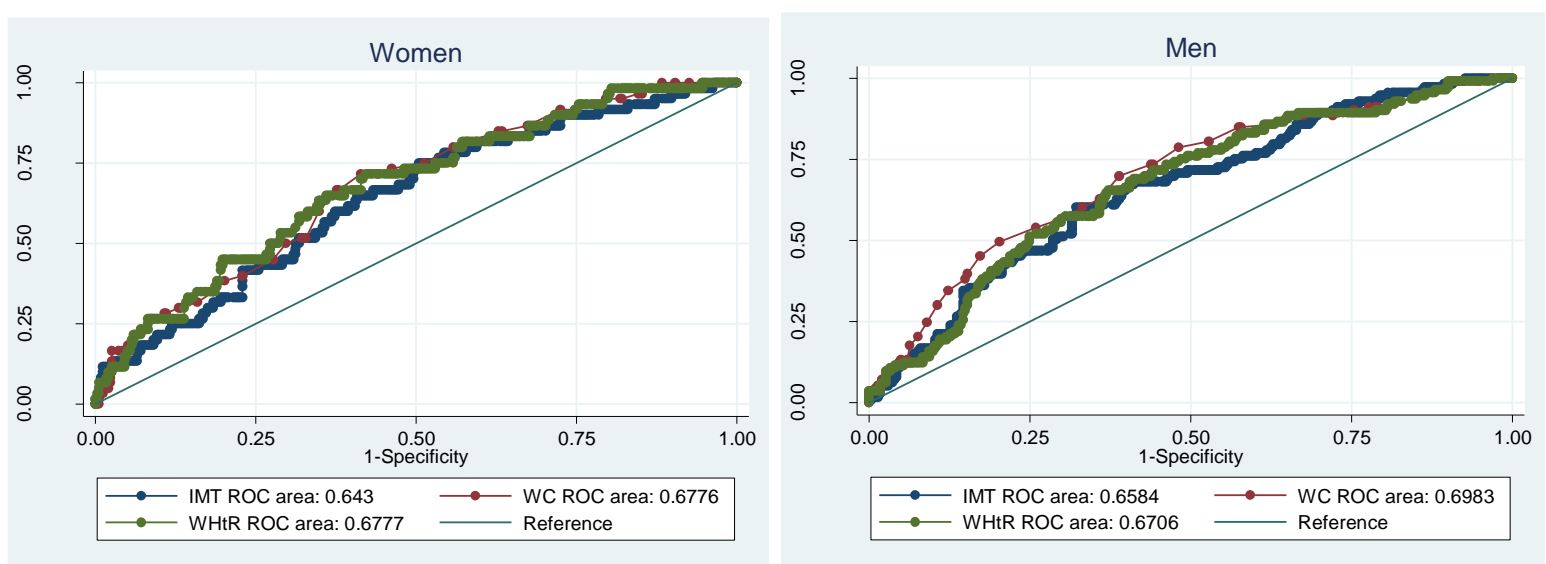

\section{Graph.2}

Receiver Operating Characteristic (ROC) Curve between BMI, WC and WHtR in Prediction Hypertension by Gender.

Based on graph.2 results of ROC curve analysis by gender obtained the highest AUC WC value for men $0.69(95 \% \mathrm{CI}=0.64-0.75)$ whereas for women the AUC value highest in WC and WHtR 0.67 $(95 \% \mathrm{CI}=0.60-0.74)$.

Table.2

Area Under the Curve (AUC) between BMI, WC and WHtR Prediction Hypertension in Age Groups by Gender.

\begin{tabular}{lcccc}
\hline \multirow{2}{*}{ Age Groups } & Total & AUC (95\% CI) & WHtR \\
\cline { 3 - 5 } Men & & BMI & WC & $0.66(0.55-0.78)$ \\
$<40$ & 171 & $0.68(0.58-0.78)$ & $0.68(0.57-0.80)$ & $0.65(0.58-0.72)$ \\
$\geq 40$ & 243 & $0.65(0.57-0.72)$ & $0.69(0.63-0.76)$ & $0.67(0.61-0.72)$ \\
Total & 414 & $0.65(0.60-0.71)$ & $0.69(0.64-0.75)$ & $0.64(0.47-0.81)$ \\
Women & & & & $0.63(0.54-0.72)$ \\
$<40$ & 224 & $0.64(0.48-0.81)$ & $0.66(0.48-0.84)$ & $0.67(0.60-0.74)$ \\
$\geq 40$ & 189 & $0.60(0.51-0.69)$ & $0.63(0.55-0.72)$ & $\mathbf{0 . 6 6}(\mathbf{0 . 6 2 - 0 . 7 0 )}$ \\
Total & 413 & $0.64(0.56-0.71)$ & $0.67(0.60-0.74)$ & $\mathbf{0 . 7 0}(\mathbf{0 . 6 6 - 0 . 7 4 )}$ \\
\hline Total & $\mathbf{8 2 7}$ & $\mathbf{0 . 6 4}(\mathbf{0 . 6 0 - 0 . 6 9 )}$ & & \\
\hline
\end{tabular}

Table. 2 showed that the results of the ROC curves analyzed by age group of each gender. The highest AUC value for men age <40 years $0.68(95 \% \mathrm{CI}=0.57-0.80)$ in $\mathrm{BMI}$ and WC, whereas for men age $\geq 40$ years the highest AUC that is WC $0.69(95 \% \mathrm{CI}=0.63-0.76)$. For women age $<40$ years, the highest AUC value was WC $0.66(95 \% \mathrm{CI}=0.48-0.84)$ and for women age $\geq 40$ years the highest AUC value that is $\mathrm{WC}$ and $\mathrm{WHtR} 0.63(95 \% \mathrm{CI}=0.54-0.72)$. 
Table.4

Results Measurement Cut-Off Points of Anthropometric Indexes Based on Age Groups in Men and Women

\begin{tabular}{|c|c|c|c|c|c|c|c|c|c|c|}
\hline \multirow{2}{*}{$\begin{array}{c}\text { Age } \\
\text { Groups }\end{array}$} & \multirow[b]{2}{*}{$\mathbf{N}$} & \multicolumn{3}{|c|}{ BMI } & \multicolumn{3}{|c|}{ WC } & \multicolumn{3}{|c|}{ WHtR } \\
\hline & & $\begin{array}{c}\text { Cut- } \\
\text { off }\end{array}$ & $\begin{array}{c}\text { Sensitivity } \\
\%\end{array}$ & $\begin{array}{c}\text { Specificity } \\
\%\end{array}$ & $\begin{array}{l}\text { Cut- } \\
\text { off }\end{array}$ & $\begin{array}{c}\text { Sensitivity } \\
\%\end{array}$ & $\begin{array}{c}\text { Specificity } \\
\%\end{array}$ & $\begin{array}{l}\text { Cut- } \\
\text { off }\end{array}$ & $\begin{array}{c}\text { Sensitivity } \\
\%\end{array}$ & $\begin{array}{c}\text { Specificity } \\
\%\end{array}$ \\
\hline \multicolumn{11}{|l|}{ Men } \\
\hline$<40$ & 171 & 26.17 & 71.43 & 65.73 & 94 & 71.43 & 61.54 & 0.57 & 60.71 & 73.43 \\
\hline$\geq 40$ & 243 & 26.64 & 57.65 & 66.46 & 94 & 69.41 & 60.76 & 0.56 & 70.59 & 56.33 \\
\hline Total & 414 & 26.64 & 60.18 & 67.77 & 94 & 69.91 & 61.13 & 0.57 & 65.49 & 62.79 \\
\hline \multicolumn{11}{|l|}{ Women } \\
\hline$<40$ & 224 & 27.42 & 58.33 & 70.75 & 91 & 58.33 & 72.64 & 0.59 & 50.00 & 73.58 \\
\hline$\geq 40$ & 189 & 26.15 & 66.67 & 54.61 & 88 & 75.00 & 52.48 & 0.56 & 70.00 & 50.35 \\
\hline Total & 413 & 26.43 & 60.00 & 62.61 & 88 & 71.67 & 58.64 & 0.56 & 71.67 & 57.79 \\
\hline Total & 827 & 25.89 & 67.05 & 57.95 & 90 & 76.30 & 54.74 & 0.56 & 68.79 & 59.02 \\
\hline
\end{tabular}

Table. 4 showed the best cut-off point for each anthropometric index in predicting hypertension were $\mathrm{BMI}=25.89 \mathrm{~kg} / \mathrm{m}^{2}$ with sensitivity $67.05 \%$ and specificity $57.95 \%, \mathrm{WC}=90 \mathrm{~cm}$ with sensitivity $76.30 \%$ and specificity $54.74 \%$ and $\mathrm{WHtR}=0.56$ with sensitivity $68.79 \%$ and specificity $59.02 \%$. Based on gender were no differences anthropometric index cut-off point among men and women except waist circumference. Measurement cut-off point waist circumference were men $94 \mathrm{~cm}$ (sensitivity 69.91\%; specificity 61.13\%) and women $\mathrm{WC}=88 \mathrm{~cm}$ (sensitivity $71.67 \%$; specificity $58.64 \%)$.

\section{DISCUSSION}

The results showed that the prevalence of hypertension among men was higher than women. This study is in line with research conducted in Iran and Egypt. ${ }^{22.23 .24}$ Hypertension in men caused by some factors like work, smoking, drinking alcohol and consumption of unhealthy foods. ${ }^{25}$ The increase of age makes blood pressure increased too because the arterial wall in the elderly will experience thickening which results in the accumulation of collagen in the muscle layer so that the blood vessels will gradually narrow and become stiff. ${ }^{1.19}$

Index anthropometrics among BMI, WC, and WHtR can predict and distinguish the risk of hypertension, dyslipidemia, and diabetes. Body fat variations are influenced by various factors such as gender, age, ethnicity and reproductive status. ${ }^{21} \mathrm{WC}$ was better predicting the risk of hypertension with the AUC value of 0.70 (95\% CI $=0.66-0.74)$ compared to BMI and WHtR. Similar result with study was found in Brazil, ${ }^{19}$ and Egypt ${ }^{16}$ also shows that WC is slightly better than BMI. ${ }^{26}$

Based on gender the anthropometric index with the highest AUC value in men were WC 0.69 (0.64-0.75) linear with the study conducted in Brazil with the AUC value 0.59 (95\% CI $=0.49-0.68)$, while in the female anthropometric index the best in predicting hypertension that is $\mathrm{WC}$ and WHtR with AUC value $0.67(95 \% \mathrm{CI}=0.60-0.74)$. Our findings are consistent with other research in Brazil where the WHtR AUC value was 0.69 (95\% CI $=0.63-0.75) \cdot{ }^{19}$ Based on the age group between men and women were not significant difference of value among $\mathrm{BMI}$, WC, and $\mathrm{WHtR}$ in 
predicting hypertension where similar result with study was conducted in Chinese people. ${ }^{27}$

Based on recommendations in general WC cut-off points were for men $94 \mathrm{~cm}$ and women $80 \mathrm{~cm}$, while those for Southeast Asia, China, and Japan cut-off points WC for men 90 $\mathrm{cm}$ and women $80 \mathrm{~cm} .{ }^{21}$ The results showed that the cut-off point for WC in men was $94 \mathrm{~cm}$, and women were $88 \mathrm{~cm}$. The results of the study that were not too different were found in South Africa $^{28}$ in men who got a cut-off point of 95.25 $\mathrm{cm} \mathrm{WC}$ and $89.45 \mathrm{~cm}$ for women. The WC cutoff point is still among the results of the study ${ }^{18}$ for the Southeast Asian population which found that in men between $93.3 \mathrm{~cm}$ to $105.2 \mathrm{~cm}$ and women between $77.4 \mathrm{~cm}$ to $95.8 \mathrm{~cm}$.

The cut-off BMI in this study found no differences between men and women. The Study in Nigeria found the same result where no differences BMI cut-off point between men and women. $^{29}$ Cut-off point BMI on men in Southern Asia is $26.5-30.4 \mathrm{~kg} / \mathrm{m}^{2}$ and women 24.9-33.3 kg/m ${ }^{2}{ }^{18}$ The mean BMI of Chinese, Indonesian and Vietnamese women were 23.1, 22.4 and 20.4, and the mean BMI of Chinese, Indonesian and Vietnamese men were 23.1, 21.2 and 20.2 respectively. ${ }^{14}$

WHtR is an alternative anthropometric index in central obesity in addition to the use of WC. The studies in Taiwan, ${ }^{30}$ Jordanian $^{31}$ and Korea, ${ }^{15} \mathrm{WHtR}$ showed better results to identify

\section{REFERENCES}

1. WHO. A global brief on Hypertension World Health Day 2013. World Health Organization. 2013. 1-40 p.

2. Kementerian Kesehatan RI. Hasil Riset Kesehatan Dasar 2013. Laporan Nasional 2013. Jakarta; 2013.

3. Riskesdas. Laporan Nasional Riset Kesehatan Dasar 2018 Kementerian Kesehatan RI. Jakarta; 2018.

4. Delaney J. Hypertension and Obesity: the risk of hypertension with cut-off point 0.50 . This study was found that the cut-off point of the WHtR 0.56. Linear with the study was found in adult Egyptians with cut-off points 0.57 in men and 0.56 in women. ${ }^{22}$

The three anthropometric indexes above with the right cut-off point can be used to detect various risk factors for metabolic diseases. ${ }^{27.32}$ From some studies of the ability of the anthropometric index to predict the risk of hypertension, the AUC values were ranged from 0.51 to $0.83 .^{12.15 .19 .22 .29 .30 .31}$

\section{CONCLUSION}

Waist circumference is the most superior anthropometric index compared to WHtR and BMI in predicting the risk of hypertension in employees Cimahi City. The results of the study can be used as a recommendation and strategy of a public health program to classify anthropometric index. Therefore can help prevent and control the obesity epidemic and warning about increasing of risk hypertension and other comorbidities associated with metabolic syndrome.

\section{ACKNOWLEDGMENT}

The author would like to thank the Cimahi City Health Office and all who helped in this research.

How Weight-loss Affects Hypertension. Obesity Action Coalition [Internet]. 2017; Available from http://www.obesityaction.org/educational -resources/resource-articles-2/obesityrelated-diseases/hypertension-andobesity-how-weight-loss-affectshypertension

5. Narkiewicz K. Obesity and hypertension - The issue is more complex than we 
thought. Nephrology Dialysis Transplantation. 2006;21(2):264-7.

6. Jiang SZ, Lu W, Zong XF, Ruan HY, Liu Y. Obesity and hypertension (review). Experimental and Therapeutic Medicine. 2016;12(4):2395-9.

7. Hall JE, Do Carmo JM, Da Silva AA, Wang Z, Hall ME. Obesity-Induced Hypertension: Interaction of Neurohumoral and Renal Mechanisms. Circulation Research. 2015;116(6):9911006.

8. Richard N. Obesity Related Hypertension. The Ochsner Journal. 2009;10(5):525-34.

9. Souza MGB de, Rivera IR, Silva MAM da, Carvalho ACC. Relationship of obesity with high blood pressure in children and adolescents. Arquivos Brasileiros de cardiology [Internet]. 2010;94(6):714-9. Available from: http://www.ncbi.nlm.nih.gov/pubmed/20 428712

10. Ningsih VR, Purba IG, Faisya AF. Analisis Determinan Kejadian Hipertensi di Puskesmas Merdeka Kota Palembang. Jurnal Ilmu Kesehatan Masyarakat. 2012;3(2):143-50.

11. CDC. The 7th Report of The JNC on Prevention, Detection, Evaluation, and Treatment of High Blood Pressure. 2003.

12. Duggleby SL, Jackson AA, Godfrey KM, Robinson SM, Inskip HM. Cut-off points for anthropometric indices of adiposity: Differential classification in a large population of young women. British Journal of Nutrition. 2009;101(3):424-30.

13. WHO. Public health Appropriate bodymass index for Asian populations and its implications for policy and intervention strategies. Lancet. 2004;363:157-63.

14. Tuan NT, Adair LS, Suchindran CM, He K, Popkin BM. The Association Between Body Mass Index and Hypertension is Different East and Southeast Asians. American Journal of Clinical Nutrition [Internet]. 2009; Available from http://trrjournalonline.trb.org/doi/10.314
1/2543-04

15. Kim SH, Choi H, Won CW, Kim BS. Optimal cut-off points of anthropometric parameters to identify high coronary heart disease risk in Korean adults. Journal of Korean Medical Science. 2016;31(1):61-6.

16. Mohamed A, El S, Zaki ME, Kandeel WA, Mohamed SK, Helmi K, et al. CutOff Values of Anthropometric Indices for the Prediction of Hypertension in a Sample of Egyptian Adults. Macedonian Journal of Medical Sciences. 2014;7(1):89-94.

17. Kemenkes RI. Pedoman Gizi Seimbang. 2014.

18. Gray LJ, Yates T, Davies MJ, Brady E, Webb DR, Sattar N, et al. Defining Obesity Cut-Off Points for Migrant South Asians. PLoS ONE. 2011;6(10):4-10.

19. Rezende AC, Souza LG, Jardim TV, Perillo NB, Araújo YCL, De Souza SG, et al. Is waist-to-height ratio the best predictive indicator of hypertension incidence? A cohort study. BMC Public Health. 2018;18(1):1-11.

20. IFPMA. Hypertension: Putting The Pressure on The Silent Killer. Geneva; 2016.

21. WHO. Waist circumference and waist-hip ratio- report of a WHO expert consultation. World Health Organization. 2008;(December):1-34.

22. Din AMS El. Cut off values of anthropometric indices for the prediction of hypertension in a sample of Egyptian adults.pdf. Macedonian Journal of Medical Sciences. 2015;

23. Babai MA, Arasteh P, Hadibarhaghtalab M, Naghizadeh MM, Salehi A, Askari A, et al. Defining a BMI cut-off point for the Iranian population: The shiraz heart study. PLoS ONE. 2016;11(8):1-12.

24. Dhika T, Syarif S. Hubungan Obesitas Dengan Kejadian Hipertensi Derajat 1 di Pos Pembinaan Terpadu Penyakit Tidak Menular ( Posbindu PTM ) Kantor Kesehatan Pelabuhan Bandung Tahun 2016. Jurnal Epidemiologi Kesehatan 
Indonesia. 2017;1(2):13-8.

25. Amanda D. Relationship of Characteristic and Status of Central Obesity with The Prevalence Of Hypertension. Jurnal Berkala Epidemiologi. 2018;6(Januari 2018):57-66.

26. Trwinarto A. Cut Off Point Body Mass Index and Abdominal Circumference as Indicator of Diabetes and Hypertension Risk Among Indonesia Adult. Penel Gizi Makan. 2012;35(2):119-35.

27. Liu Y, Tong G, Tong W, Lu L, Qin X. Can body mass index, waist circumference, waist-hip ratio, and waistheight ratio predict the presence of multiple metabolic risk factors in Chinese subjects? BMC Public Health [Internet]. 2011;11(1):35. Available from: http://www.biomedcentral.com/14712458/11/35

28. Owolabi EO, Goon D Ter, Adeniyi OV, Ajayi AI. Optimal waist circumference cut - off points for predicting metabolic syndrome among low - income black South African adults. BMC Research Notes [Internet]. 2018;1-5. Available from: https://doi.org/10.1186/s13104018-3136-9

29. Ononamadu CJ, Ezekwesili CN, Onyeukwu OF, Umeoguaju UF, Ezeigwe
OC, Ihegboro GO. Comparative analysis of anthropometric indices of obesity as correlates and potential predictors of risk for hypertension and prehypertension in a population in Nigeria. Cardiovascular Journal of Africa [Internet]. 2017;28(2):92-9. Available from: http://cvja.co.za/onlinejournal/vol28/vol2 8 issue 2/\#26/z

30. Li WC, Chen IC, Chang YC, Loke SS, Wang SH, Hsiao KY. Waist-to-height ratio, waist circumference, and body mass index as indices of cardiometabolic risk among 36,642 Taiwanese adults. European Journal of Nutrition. 2013;52(1):57-65.

31. Khader YS, Batieha A, Jaddou H, Batieha Z, El-Khateeb M, Ajlouni K. Anthropometric cut off values for detecting metabolic abnormalities in Jordanian adults. Dove Press [Internet]. 2010;3:395-402. Available from: http://www.pubmedcentral.nih.gov/article render.fcgi?artid=3047991\&tool=pmcent rez\&rendertype $=$ abstract

32. Al-lawati JA, Jousilahti P. Body mass index, waist circumference and waist-tohip ratio cut-off points for categorization of obesity among Omani Arabs. Public Health Nutrition. 2007;11(1):102-8. 